Just War and Military Morale - a brief reflection on the correlation between the legality of war and the moral repercussions for members of US and UK forces arising from the questionable legality of the campaign Iraqi Freedom of March 2003.

\begin{abstract}
Does it matter to a member of the military whether the military campaign in which he is taking part is lawful or not? Despite the observation that the crime of aggression (post Kampala 2010) constitutes a "leadership crime par excellence," which limits any (future) criminal responsibility accordingly, the legality or illegality of any military action under international law can create moral implications for the common foot soldier and mid-level officer and also have a tangible impact on the national legal frameworks under which these forces operate. This short article uses the example of Operation Iraqi Freedom (2003) to discuss the repercussions of a - most likely - illegal military campaign for individual members of democratic armed forces before the background of the present discussion of NATO led action in Libya.
\end{abstract}

Key words: Armed Conflict - Legality of the Use of Force - Military Morale - Court Martials - Operation Iraqi Freedom - Crime of Aggression 


\section{Just War and Military Morale - a brief reflection on the correlation between the legality of war and the moral repercussions for members of US and UK forces arising from the questionable legality of the campaign Iraqi Freedom of March 2003.}

\section{SASCHA-DOMINIK BACHMANN *}

The events of the so called Jasmine revolution, as the Arab spring ${ }^{1}$ of democratic change was labelled, changed, or at least challenged, the political landscape in the Maghreb, the Arab and Mid-Eastern world in general and in Libya in particular. These events also highlighted how quickly NATO and the European Union could be facing future calls for military action when asked or compelled to contribute militarily to peace and security operations in the region: highlighted by the present NATO led military operation in Libya to enforce the "No Fly Zone”, established under UN SC Resolution 1973 (2011) to protect Libyan civilians in the Libyan Arab Jamahiriya. ${ }^{2}$

Last decade, it were the attacks on 11 September 2001 on the United States of America, executed by mostly Saudi-born terrorists, which led as a consequence to the so-called 'war on terror'. The scope of the " $9 / 11^{\text {"3 }}$ attacks warranted its categorization as an "armed attack by conventional means” on the $\mathrm{USA}^{4}$ and triggered two military campaigns ${ }^{5}$ of doubtful

\footnotetext{
* Senior Lecturer in Law; Assessor Jur, LL.M, LL.D; Sascha-Dominik teaches international law at the School of Law, University of Portsmouth. Outside academics his professional experience includes working in various capacities as an Army reserve officer and taking part in peacekeeping missions in operational and advisory capacities.

${ }^{1}$ Aptly reiterating the hopes associated with the Prague spring of 1968 which led after an initial period of hope for democratic change to the military crushing by Soviet led invasion forces.

${ }^{2}$ UN S/RES/1973 (2011), which was adopted after the Arab League asked the United Nations in a resolution of 12 March 2011 to establish and enforce such a "no fly zone” in Libya.

${ }^{3}$ The term refers to the infamous attacks on the World Trade Center and the Pentagon by Arab terrorists of the Al-Qaeda network, which took place on 11-09-2001, in which some 3000 people lost their lives. Cf. McGoldrick From "9-11" to the Iraq War 2003 (2004) 9-11; also referred to as 9/11 attacks.

${ }^{4}$ See Fournet International Crimes: Theories, Practice and Evolution (2006) 164 and Gray International Law and the Use of Force (2004), 165 - 167 on the new nature of the concept of armed attack after 9/11.

${ }^{5}$ The US led military campaign in Afghanistan since autumn 2001 was named "Operation Enduring Freedom" (OEF) and targets remaining Taleban and Al-Qaeda structures; besides OEF operates the UN mandated international assistance mission of the International Security and Assistance Force (ISAF), see Security Council resolution 1386. The second ongoing military operation takes place in Iraq and is called as "Operation Iraqi Freedom” (OIF).
} 
legality ${ }^{6}$ under international law: 'Operation Enduring Freedom’ in $2001^{7}$ was followed by 'Operation Iraqi Freedom' in 2003. ${ }^{8}$ The lawfulness of both campaigns, involving invasion and subsequent 'regime-change' by the American-led coalition, will be debated for some time to come. ${ }^{9}$ Despite this debate and ongoing enquiries (such as the UK Iraq enquiry) ${ }^{10}$ it seems that there will be no real possibility that any (international) criminal law action will be taken against any individual leader relating to the invasion of Iraq for the crime of aggression. This omission has to be seen in the context of the legal and moral perception we have of the law of Nuremberg. ${ }^{11}$

Before this background and the ongoing volatile situation in the Maghreb, this short article uses the example of the Operation Iraqi Freedom of 2003 to discuss the repercussions of a most likely - illegal military campaign for individual members of democratic armed forces. ${ }^{12}$

\footnotetext{
${ }^{6}$ See Van der Vyver 'Ius contra bellum and American foreign policy' 28 South African Yearbook of International Law (2003) 1-28; Brunée \& Toope 'Slouching towards new 'just' wars: international law and the use of force after September $11^{\text {th }}$ (2004) 51 Netherlands International Law Review 363-392.

${ }^{7}$ See Kritsiotis ‘On the Jus ad bellum and Jus in bello of Operation Enduring Freedom’ ASIL Proceedings 2002, 35-41.

${ }^{8}$ For a compilation of commentary and legal analyses of the Iraq War, see American Society of International Law Future Implications of the Iraq Conflict (2003); McGoldrick (n 3) 47-51 for a comprehensive discussion of the legal debate on the Iraq War.

${ }^{9}$ Which was neither explicitly authorised by the UN Security Council, nor an apparent act of self-defence under Article 51 of the UN Charter For comments on the legality of the 2003 invasion of Iraq, see Fisler- Damrosch and Oxman (eds) Future Implications of the Iraq Conflict (2003).

${ }^{10}$ Go to http://www.iraqinquiry.org.uk/ for info on the enquiry, evidence heard so far and background documents.

${ }^{11}$ Consisting of the (London) Agreement, the Nuremberg Charter and its subsequent Control Council Law No. 10 of Dec 1945.

${ }^{12}$ This contextual article partly reflects on some aspects of the author's previous joint research (Bachmann \& Kemp, "The international crime of aggression in the context of the global "war on terror": some legal and ethical perspectives”, 2 JSAL 2010, 309 - 330).
} 